\title{
Trend in Cost of Cultivation of Sorghum in Andhra Pradesh and Telangana States of India
}

\author{
Perka Shiva Kumar ${ }^{1}$, G.P. Sunandini ${ }^{2}$ and K. Suhasini ${ }^{3}$ \\ ${ }^{1}$ Scientist, Cost of Cultivation Scheme, Department of Agricultural Economics, Regional Agricultural Research Station, Warangal, \\ Professor Jayashankar Telangana State Agricultural University, Telangana, India \\ ${ }^{2}$ Principal Scientist, Cost of cultivation Scheme, Department of Agriculture Economics, College of Agriculture, Professor Jayashankar \\ Telangana State Agricultural University, Telangana, India \\ ${ }^{3}$ Professor \& University Head Department of Agriculture Economics, College of Agriculture, Professor Jayashankar Telangana \\ State Agricultural University, Telangana, India
}

*Corresponding author: shiva_perka1990@yahoo.com (ORCID ID: 0000-0001-7033-3554)

Received: $14-08-2020$

Revised: 23-11-2020

Accepted: 06-12-2020

\begin{abstract}
Area and production of Sorghum in Andhra Pradesh state increased by $6.8 \%$ and $9.7 \%$ but decreased by $12.1 \%$ and $9.8 \%$ in Telangana state, respectively since the last few years whereas the average yield was increased by $2.6 \%$ in both the states. The cost of production of sorghum was raised by $11-14 \%$ but the market price was increased by $7.5 \%$ only. Cost of production C2 was overlapped with the market price up to 2012-13 but later on, the market price was lower than C2 whereas the cost of production A2 overlapped with Minimum Support Price up to 2011-12 but MSP was quite higher after 2011-12. Operational costs ranged from $62-66 \%$ and fixed costs are $34-38 \%$ out of the total cost of cultivation of sorghum. The inverse relationship between yield and cost of production has proved in the log-linear regression model at $5 \%$ level of significance, due to low productivity of crop, still, there is need to develop High Yielding Varieties at State Agriculture Universities of both the states, modern technologies are to be adopted by the farmers to improve the productivity. In view of the importance of crops the government has to raise the remunerative market price and public awareness is to be created about the nutritional importance of crops so that the cropped area might be increased. Processing industries are to be encouraged on a large scale which generates employment for the rural youth; some more need-based processing technologies are to be developed at research institutes.

Highlights

( S Sorghum is a climate-resilient and most important staple food crop for millions of poor rural people throughout the world with a principal source of energy, protein, vitamins, and minerals.

( $)$ The study revealed the trends of, area, production, yield, and cost structure of Sorghum crop since the last few years in Andhra Pradesh and Telangana states of India.
\end{abstract}

Keywords: Sorghum, cost of cultivation, cost of production, growth rate

Sorghum has been, for centuries, one of the most important staple foods for millions of poor rural people in the semiarid tropics of Asia and Africa. Grain sorghum is the fifth most important cereal crop grown across the world. India is the fifthlargest producer (4.5 Million tons,) (FAO, 2017) of Sorghum after the United States of America (9.2 MT), Nigeria (6.8 MT), Mexico (4.85 MT), and Ethiopia (4.81 MT). In India, Maharashtra (1.6 MT) (DES, GoI, 2017-18) is the lead producer followed by Karnataka (1.1 MT), Andhra Pradesh is in $6^{\text {th }}$ position with a production of 3 lakh tons occupying an area of 1.4 lakh hectare covering the major districts Ananthapuram, Kurnool and YSR Kadapa. The area of sorghum in Telangana state is 67,000 hectares with a production of 73,000 tons; major districts are Asifabad, Kamareddy, and Sangareddy. Dayakar et al. (2015) emphasized that the Sorghum consumption in India is not significantly exploited

How to cite this article: Kumar, P.S., Sunandini, G.P. and Suhasini, K. (2020). Trend in Cost of Cultivation of Sorghum in Andhra Pradesh and Telangana States of India. Economic Affairs, 65(4): 505-509.

Source of Support: None; Conflict of Interest: None (क) क्ष 
to commercialize their importance as health or prophylactic food, despite offering well-balanced composition of carbohydrates, proteins, and minerals together with high dietary fiber. Sorghum grain has high fiber content, moderate digestibility, and rich mineral content compared to other cereals such as rice and wheat. Therefore sorghum foods are recommended for diabetes and for fighting obesity. Being free from gluten, sorghum is the ideal food for celiac patients and other lifestyle diseases. Sorghum possesses unique nutritional and functional properties that can lead itself to the development of healthy and nutritious foods at low costs. Rahman and Bee, 2019 stated that sustained growth in crop production can be achieved by providing sustainable growth in profitability, fuelled with higher yield increase, outpaces the growth in the cost of production. Sufficient returns from the crop encourage farmers to continue with the crop over the years in the cropping system and also effect changes in crop mix in the non-traditional areas. Hence there is a need to understand whether the cost of cultivation of the crop is raising or profitability shrinking? Against this backdrop, it is pertinent to know the changes in the cost of cultivation and profitability of sorghum over a period of time. In view of this literature, the study attempted to find out the trends in the costs and returns of sorghum to assess the profitability.

\section{MATERIALS AND METHODS}

Sorghum area, production, and productivity of Andhra Pradesh and Telangana states were collected from Directorate of Economics and Statistics, GoI, for the seven years from 2010-11 to 2017-18. Sorghum cost of cultivation data of combined Andhra Pradesh state was taken from the reports of Directorate of Economics and Statistics GoI, for eleven years pertaining the period of 2005-06 to 2016-17 in which the cost of cultivation and production data was represented which was analyzed by using cost concepts method.

The compound annual growth rates are calculated by using the formula:

CAGR $=(\text { Ending Value/Beginning Value })^{(1 / n)}-1$ $n=$ Number of Periods (Months, Years, etc.)

Production function analysis was done to identify the relationship between the cost of production and yield. The yield elasticity of production cost was estimated by fitting the log-linear regression function.

The general form of the cost function is given by the following Equation.

Cost of production $=f$ (crop yield, seed cost, human labor cost, machinery cost, animal labor cost, fertilizer quantity, pesticides cost)

\section{RESULTS AND DISCUSSION}

\section{Area, Production, and Yield of Sorghum}

Table 1 revealed that the Sorghum area was increased by $6.87 \%$ in Andhra Pradesh state for the period of $2010-11$ to $2017-18$, whereas it was decreased by $12.16 \%$ in Telangana because of the diversification of farmers to huge demanding crops like cotton, paddy, and maize. The production also followed the trends of the area in both the states, rabi sorghum yield was increased but kharif yield was declined in both the states with an overall increase of $2.6 \%$ of yield for the last eight years.

Table 1: Compound Annual Growth Rates (CAGR) of Area, Production, and Yield of Sorghum in Andhra Pradesh and Telangana states from 2010-11 to 2017-18

\begin{tabular}{llll}
\hline Andhra Pradesh & Area & Production & Yield \\
\hline Kharif & $18.92 \%$ & $13.11 \%$ & $-4.88 \%$ \\
Rabi & $4.84 \%$ & $9.39 \%$ & $4.34 \%$ \\
Total & $6.87 \%$ & $9.73 \%$ & $2.67 \%$ \\
\hline Telangana & Area & Production & Yield \\
\hline Kharif & $-11.98 \%$ & $-12.22 \%$ & $-0.27 \%$ \\
Rabi & $-12.48 \%$ & $-6.00 \%$ & $7.40 \%$ \\
Total & $-12.16 \%$ & $-9.87 \%$ & $2.61 \%$ \\
\hline
\end{tabular}

\section{The trend in Sorghum cost of cultivation}

Fig. 1 depicting that all the costs A1, A2, B1, B2, C1, and $\mathrm{C} 2$ are following the same trend and raised by around $10 \%$ given in Table 2, Growth Rate of yield is negative $(-3 \%)$ when we observe the last eleven years data, the average yield ranging from $12.73 \mathrm{qtl}$ to $16 \mathrm{qtl}$ and it was highest at Triennium Ending (TE) 2010-11, implicit rate of sorghum has increased by $7.58 \%$ only and it was maximum at TE $2013-14$ i.e., ₹ 2785.81. Gross income also highest during the same period, net returns over cost $\mathrm{C} 2$ are negative for all the periods except in TE 2013-14 due to the presence of more implicit rate, net returns over cost 
Table 2: Cost of cultivation of Sorghum in combined Andhra Pradesh state from TE 2007-08 to TE 2016-17

\begin{tabular}{llllll}
\hline Cost (₹/Ha) & TE 2007-08 & TE 2010-11 & TE 2013-14 & TE 2016-17 & CAGR \\
\hline Cost A1 & 7786.09 & 13001.26 & 14642.22 & 17688.15 & $10.04 \%$ \\
Cost A2 & 7813.21 & 13524.08 & 14642.22 & 17747.20 & $9.93 \%$ \\
Cost B1 & 8700.45 & 14255.44 & 15867.09 & 20216.89 & $10.33 \%$ \\
Cost B2 & 12165.65 & 22618.06 & 25029.61 & 30794.93 & $9.38 \%$ \\
Cost C1 & 10241.06 & 18116.05 & 20023.10 & 26863.58 & $11.89 \%$ \\
Cost C2 & 13706.26 & 26478.66 & 29185.62 & 37411.62 & $10.72 \%$ \\
Yield (q/ha) & 12.73 & 16.08 & 13.50 & 15.45 & $-3.00 \%$ \\
Implicit rate (₹/q) & 866.34 & 1602.96 & 2785.81 & 1842.29 & $7.58 \%$ \\
Gross income (₹/ha) & 11028.50 & 25775.6 & 37608.4 & 28463.4 & $5.36 \%$ \\
Net Returns over cost C2 & -2677.75 & -703.06 & 8422.82 & -8948.2 & \\
Net Returns over cost A2 & 3215.29 & 12251.5 & 22966.2 & 10716.2 & \\
\hline
\end{tabular}

A2 are highly varied during all the periods and it is ₹ 10716 at TE 2016-17.

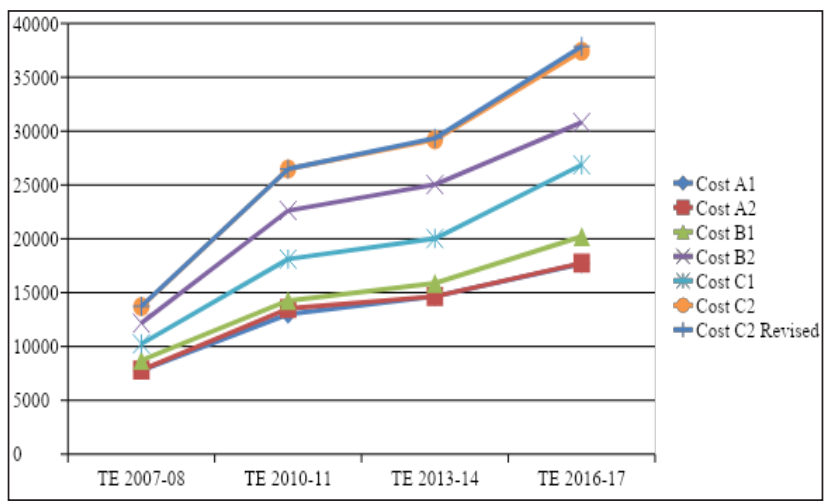

Fig. 1: Trends in Sorghum cost of cultivation

\section{The trend in Sorghum cost of Production}

Table 3 explaining that the different levels of cost of production A1, A2, B1, B2, C1, and C2 are showing positive growth rates and it is ranging around $11-14 \%$, Fig. 2 depicting that the cost C2 is almost overlapped with market prices up to 201213 but in 2013-14 the market price was highest due to less production and in 2016-17 cost C2 was around ₹ 3000 which is higher than the market price as well Minimum Support Price (MSP). Cost A2 is overlapped with MSP up to 2011-12 but MSP was quite higher after 2011-12, from this it was understood that through MSP farmers realizing only the expenditure on inputs, these results concur with Dayakar Rao and Latika Devi, 2016 in which Rajasthan, Maharashtra, and Karnataka state data were analyzed.
Table 3: Cost of production of Sorghum in combined Andhra Pradesh state from TE 2007-08 to TE 2016-17

\begin{tabular}{llllll}
\hline $\begin{array}{l}\text { Cost } \\
\text { (₹/q) }\end{array}$ & TE 2007- & TE 2010- & TE 2013- & TE 2016- & CAGR \\
\hline Cost A1 & 528.47 & 787.02 & 1255.79 & 973.72 & $12.40 \%$ \\
Cost A2 & 529.77 & 841.16 & 1255.79 & 974.73 & $12.30 \%$ \\
Cost B1 & 591.01 & 870.26 & 1328.57 & 1115.77 & $12.76 \%$ \\
Cost B2 & 829.19 & 1303.38 & 2069.96 & 1655.42 & $11.44 \%$ \\
Cost C1 & 698.74 & 1081.02 & 1707.13 & 1511.54 & $14.54 \%$ \\
Cost C2 & 936.92 & 1514.13 & 2448.52 & 2051.19 & $13.00 \%$ \\
\hline
\end{tabular}

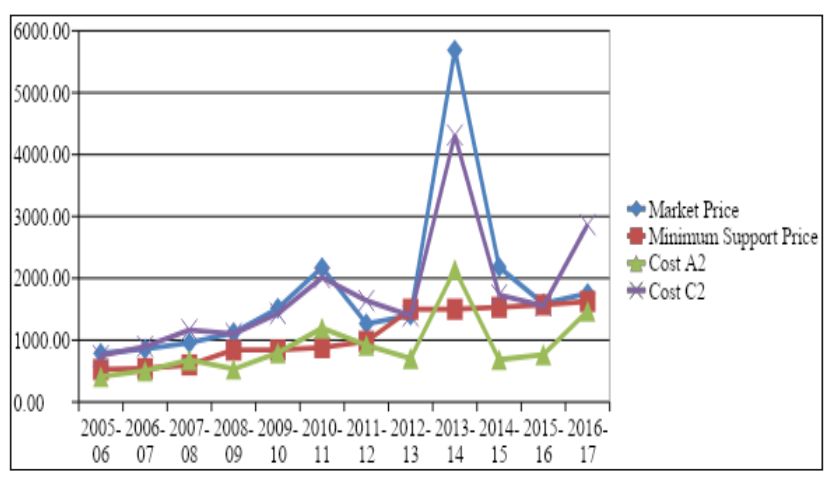

Fig. 2: Trends showing the Cost of Production (A2, C2), MSP, and Market prices of Sorghum

\section{Item wise Breakup of Cost of Cultivation (₹/ha) of Sorghum}

Item wise Breakup of Cost of Cultivation of Sorghum at each Triennium Ending was given in Table 4, in total cost human labor cost accounts for the highest percentage which is ranging from $32-37 \%$, showing a positive growth rate of $13.39 \%$, animal labor, and machine labor cost also raised 
Table 4: Item wise Breakup of Cost of Cultivation (₹/ha) of Sorghum in combined Andhra Pradesh state from TE 2007-08 to TE 2016-17

\begin{tabular}{llllll}
\hline Cost items & TE 2007-08 & TE 2010-11 & TE 2013-14 & TE 2016-17 & CAGR \\
\hline Total Human labor & $4377(32)$ & $9804(37)$ & $9696(33)$ & $11897(32)$ & $13.39 \%$ \\
Total animal labor & $1976(14)$ & $2410(9)$ & $2313(8)$ & $3044(8)$ & $9.84 \%$ \\
Total machine labor & $489(4)$ & $1476(6)$ & $2126(7)$ & $3679(10)$ & $10.65 \%$ \\
Seed & $268(2)$ & $451(2)$ & $943(3)$ & $987(3)$ & $16.93 \%$ \\
Fertilizer and manure & $1453(11)$ & $1714(6)$ & $1768(6)$ & $2740(7)$ & $8.28 \%$ \\
Insecticides & $106(1)$ & $68(0)$ & $617(2)$ & $421(1)$ & $6.65 \%$ \\
Irrigation & $77(1)$ & $167(1)$ & $571(2)$ & $403(1)$ & $25.36 \%$ \\
Miscellaneous & $11(0)$ & $4(0)$ & $49(0)$ & $0(0)$ & $0.00 \%$ \\
Interest in Working Capital & $226(2)$ & $382(1)$ & $435(1)$ & $517(1)$ & $10.03 \%$ \\
Operational Cost & $8983(66)$ & $16477(62)$ & $18517(63)$ & $23687(63)$ & $11.89 \%$ \\
The rental value of their own land & $3438(25)$ & $7840(30)$ & $9162(31)$ & $10519(28)$ & $7.05 \%$ \\
Rent paid for leased in land & $27(0)$ & $523(2)$ & $0(0)$ & $59(0)$ & $7.23 \%$ \\
Land revenue, taxes, cesses & $3(0)$ & $3(0)$ & $1(0)$ & $1(0)$ & $-9.09 \%$ \\
Depreciation on implements \& farm buildings & $341(2)$ & $382(1)$ & $280(1)$ & $616(2)$ & $10.39 \%$ \\
Interest on fixed capital & $914(7)$ & $1254(5)$ & $1225(4)$ & $2529(7)$ & $12.35 \%$ \\
Fixed Costs & $4724(34)$ & $10002(38)$ & $10669(37)$ & $13724(37)$ & $8.36 \%$ \\
Total Cost & $13706(100)$ & $26479(100)$ & $29186(100)$ & $37412(100)$ & $10.72 \%$ \\
\hline
\end{tabular}

Figures in the () parentheses are percentage to the total.

by $9.84 \%$ and $10.65 \%$ respectively, machine labor occupied $10 \%$ in total cost at TE 2016-17, seed cost accounts for less percentage $(2-3 \%)$ in the total but it has a positive growth rate of $16.93 \%$, regarding fertilizers and manures urea and FYM will be applied to sorghum crop which accounts for $7-11 \%$ in total cost, its expenditure increased by $8.28 \%$, farmers spending less amount on pesticides for sorghum crop ranging from $0-2 \%$, and irrigation also accounts for less percentage but it is showing increased growth rate $(25.36 \%)$, mostly nominal charges on canal water will be collected from farmers by the government, interest on working capital also occupies less percentage in the total cost. Overall operational costs ranging from $62-66 \%$ and fixed costs are $34-38 \%$ in total.

\section{The trend in inputs utilization}

The trend in input utilization of sorghum was depicted in Fig. 3, seed rate used by farmers are ranging from $10-12 \mathrm{~kg} / \mathrm{ha}$ which is more than recommended (7.5-9 kg/ha): generally, farmers use more seed to avoid gap filling, seed rate was not changed much over the period of time, fertilizer application to sorghum was raised up to 2010-11 $(137 \mathrm{~kg} / \mathrm{ha})$, later it was declined and in the recent years again increasing. Manure application is almost zero to sorghum in recent days. Animal labor usage has fallen in 2013-14 and it is rising up recently, family labor usage is low in 2013-14 and 2015-16 years due to drought prevalence, otherwise it is increasing quite since the decade, casual labour usage has decreased up to 2009-10, it is maximum in 2010-11, later on declining due to the availability of machines.

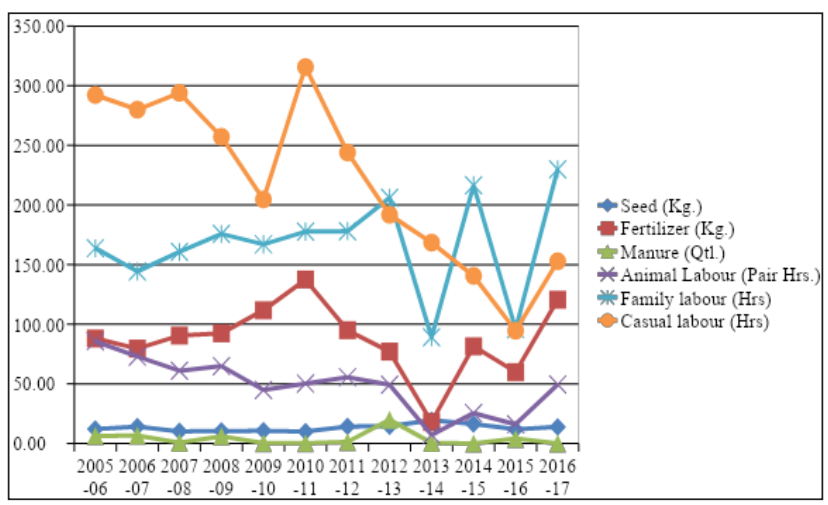

Fig. 3: Trend showing input levels per hectare

\section{Effect of yield and inputs on Cost of production}

The results of log-linear regression analysis were given in Table 5, the inverse relationship between 
the cost of production and yield has proved in the model at $5 \%$ level of significance, remaining all other variables included in the model are nonsignificant, fertilizer quantity is negatively related with production cost. The results have coincided with Srivastava et al. (2017) and Sharma, (2016).

Table 5: Results of log-linear regression analysis

\begin{tabular}{llll}
\hline Variable & b- value & $\begin{array}{l}\text { Standard } \\
\text { error }\end{array}$ & t- value \\
\hline Intercept & 1.678 & 0.435 & $3.858^{* *}$ \\
X $_{1}$-Yield (q) & -0.871 & 0.299 & $-2.913^{* *}$ \\
X-Fertilizer (Kg) $_{2}$ & -0.059 & 0.176 & -0.334 \\
X $_{3}$-Human Labour (₹) & 0.386 & 0.206 & 1.875 \\
X $_{4}$-Animal labour (₹) & 0.037 & 0.196 & 0.191 \\
X $_{5}$-Machine labour (₹) & 0.202 & 0.167 & 1.208 \\
X $_{6}$-Seed (₹) & 0.113 & 0.211 & 0.537 \\
\hline$X_{7}$-Insecticides (₹) & 0.016 & 0.039 & 0.418 \\
\hline
\end{tabular}

$Y=$ Cost of production; $R^{2}=0.977 ; R^{2}$ adj. $=0.937 ; N=12 ;{ }^{* *}=$ significant at $5 \%$ level

\section{CONCLUSION}

The average yield of sorghum in India is $0.7 \mathrm{t} /$ ha only whereas in countries like the USA and Mexico average yield is $4.5 \mathrm{t} / \mathrm{ha}$ and $3.3 \mathrm{t} / \mathrm{ha}$ respectively, hence there is a need to develop High Yielding Varieties and hybrids at State Agriculture Universities of both the states, however, till now most of the varieties or hybrids are released by ICAR-IIMR only. Modern technologies like drone application and fertigation etc are to be adopted by the farmers to improve productivity. Regarding market price, the government has raised the Minimum Support Price to ₹ 2620 in 2020-21, but on the other side input costs also raised, the divergence between the cost of production and market price and Minimum Support Price is prominent over the period which will deter the farmers to cultivate the Sorghum crop, given the importance of crop the government has to stabilize the remunerative market price; Public awareness has to be created about the nutritional importance and health benefits of sorghum to improve crop area. Processing industries are to be encouraged on a large scale which generates employment for the rural youth; some more need-based processing technologies are to be developed at research institutes.

\section{REFERENCES}

Dayakar Rao, B. and Devi, L. 2016. Trend in cost of cultivation and profitability of sorghum cultivation, Ind. Farmi., 65(12): 87-88.

Dayakar Rao, D., B., Patil, J.V. and Chavan, U.D. et al. 2015. Emerging competitiveness of Sorghum in India: $A n$ Intensive on-farm analysis of major rabi sorghum regions. ICAR-IIMR, Rajendranagar, Hyderabad, pp. 144. ISBN: 81-89335-51-0

Directorate of Economics and Statistics. 2018. https://eands. dacnet.nic.in

FAO Stat. 2017. http://www.fao.org

Rahman, F. and Bee, N. 2019. Trends and Pattern of Sugarcane Production in Shahjahanpur District, Uttar Pradesh: A Geographical Analysis, Econ. Affairs, 64(3): 537-545.

Srivastava, S.K., Chand, R. and Singh, J. 2017. Changing Crop Production Cost in India: Input Prices, Substitution and Technological Effects, Agricultural Economics Resea. Rev., 30: 171-182.

Sharma, P. 2016. Costs, returns and profitability of soybean cultivation in India: Trends and prospects, Econ. Affairs, 61(3): 413-425. 
